Anna Łazuchiewicz

\title{
ŻyCie CesarzoWej Ireny z Aten WEDEUg TeOfanesa WYZNAWCY
}

W niniejszej pracy zajmę się cesarzową Ireną i polityką religijną przez nią prowadzoną. Omówione zostaną istotne zagadnienia związane $\mathrm{z}$ jej panowaniem, wraz z najważniejszym, mającym miejsce w 787 roku, kiedy to udało jej się na 27 lat przywrócić kult ikon.

Ramy chronologiczne niniejszego opracowania obejmują trudne dla Bizancjum czasy, lata 726-803. Państwo pogrążone było w poważnym kryzysie. Nękały je $\mathrm{w}$ tym czasie nie tylko problemy religijne, ale również inne przeciwności: seria klęsk żywiołowych (trzęsienie ziemi w październiku 740 roku, które zniszczyło Konstantynopol, powrót epidemii dżumy, surowa zima 763-7641). Dodatkowo kryzys pogłębiały liczne wojny prowadzone przez cesarzy (Leona III, Konstantyna V) z Arabami i Bułgarami.

Nie posiadalibyśmy tylu informacji na temat cesarzowej Ireny, gdyby nie Kronika (Chronographia) Teofanesa Wyznawcy². Dzięki temu dziejopisowi znane są fakty z życia cesarzowej. Teofanes Wyznawca żył na dworze władców bizantyńskich i znał ich dzieje. Szczególnie dobrze mógł poznać władców z dynastii syryjskiej, czyli Konstantyna V, Leona IV, cesarzową Irenę i Konstantyna VI. Ten dziejopis opisuje wydarzenia w Bizancjum od $284 \mathrm{r}$. Swoją historię przedstawił w ujęciu chronologicznym. Działając na dworze bizantyńskim, pisał pod protektoratem różnych władców (Nikefora I, Stauracjusza). W porównaniu do jemu współczesnych Teofanesa Wyznawcę można nazwać „renesansowym mężem”. Napisał pracę rozległą i obszerną, bo sięgającą do 813 roku. Miał ogromny wpływ na literaturę zarówno Wschodu, jak i Zachodu.

\footnotetext{
${ }^{1}$ J. Shepard, Bizancjum ok. 500-1024, tłum. K. Pachniak, J.S. Partyka, R. Piotrowski, Warszawa 2012, s. 255.

${ }^{2}$ S [ancti] P[atris] N[ostri] Theophanis, abbatis Agri atque confessoris, Chronographia annorum DXXVIII, [w:] Patrologia Graeca, t. CVIII, 55-1008. W niniejszej pracy wykorzystano przekład angielski: The Chronicle of Theophanes Confessor, transl. C. Mango, R. Scott, Oxford 1997 (dalej: TeOFANES, Chr.).
} 


\section{Pochodzenie cesarzowej i lata jej młodości (750-768)}

Irena z Aten urodziła się między rokiem 750 a 755 . Można to wywnioskować na podstawie wieku jej męża, który w momencie zaślubin zbliżał się do dwudziestki, a Irena miała wówczas około czternastu-piętnastu lat. Wybór narzeczonej dla syna Leona przez Konstantyna V wynikał zapewne z faktu popierania przez jej rodzinę obrazoburstwa. Dodatkowo na wybór małżonki dla syna wpływała potrzeba połączenia z Konstantynopolem rodów z terenów Hellady. Brak pewnych informacji na temat młodości cesarzowej Ireny. Niewykluczone, że urodziła się w zamożnej greckiej rodzinie. Konstantyn V zapewne usłyszał o Irenie w 765-766 roku, za pośrednictwem rzemieślników specjalizujących się w ceramice, którzy pracowali u jej ojca. $Z$ chwilą ukończenia przez syna dziewiętnastu lat cesarz rozpoczął poszukiwania odpowiedniej dla niego małżonki. Musiał podjąć rozsądną decyzję, ponieważ od tego związku mogło zależeć umocnienie wpływów Cesarstwa Bizantyńskiego w Helladzie. Historycy nie mogą odtworzyć drzewa genealogicznego cesarzowej Ireny, gdyż dysponują zbyt małym zasobem źródeł na ten temat. Nieużywanie przez Irenę przydomka jej rodziny (Sarandapechys) wskazuje na to, że jej ojciec mógł wtedy już nie żyć (a to ojcostwo decydowało o nazwisku rodowym) lub że samo nazwisko nie cieszyło się popularnością. Później utrzymywała ona na dworze, że jest sierotą ${ }^{3}$. Brak pewnych informacji w źródłach utrudnia poznanie historii jej rodziny. Znane są fakty dotyczące takich krewnych, jak nieznana $\mathrm{z}$ imienia żona chagana bułgarskiego Teleryga, oraz Teofano, która wyszła za następcę tronu bułgarskiego Stauracjusza. Wiadomo, że Irena miała rodzeństwo, ponieważ w późniejszych źródłach można znaleźć informacje o jej bratanku lub siostrzeńcu. Wszystko wskazuje na to, iż nie był to zbytnio uprzywilejowany ród, dopiero po przejęciu przez Irenę władzy w cesarstwie można odnaleźć członków jej rodziny na wyższych szczeblach greckiej arystokracji.

Rody Hellady nosiły bardzo charakterystyczne nazwy, powiązane zapewne z cechami odróżniającymi dany ród spośród innych. Przodkowie Ireny od dawna zamieszkiwali tereny Aten i znani byli pod przydomkiem (Tes)sarandapechys. Dosłownie oznacza to 'Czterdziestokawałkowy, Czterdziestołokciowy'. Niewykluczone, że któryś z członków lub praprzodek rodu był wysokiego wzrostu. Takie przezwiska posiadały liczne rodziny z tamtego okresu, np. Lachanodrakon ('Gąsienica kapuściana') czy Koutzodaktylos ('Krótkopalcy'). Innego rodzaju są nazwy, które wiążą się z pochodzeniem geograficznym danej rodziny, np. Damaskenos, Sinaites lub Paflagonites, albo zawodami: Mydlarz czy Świecarz ${ }^{4}$.

W XIII i IX wieku zapanowała moda na wybieranie cesarskich małżonek z prowincjonalnych rodów (Irena z Aten, Maria z Amnii, Teodora z Paflagonii). Legenda głosi, że Maria i Teodora zostały wybrane na otwartym konkursie piękności. Podczas prezentacji kandydatek na małżonki decydowała nie tylko ich uroda,

\footnotetext{
${ }^{3}$ J. Herrin, Krwawe cesarzowe, przeł. Z. Simbierowicz, Warszawa 2001, s. 70.

${ }^{4}$ Ibidem, s. 70.
} 
ale również stosunek dworu do danej kobiety. Często wybór narzeczonej wiązał się z negocjacjami dyplomatycznymi i kobiety przybywały z obcych krajów, aby przypieczętować ważne sojusze 5 .

Zwięzłą informację na temat przybycia Ireny do Konstantynopola znajdujemy również w Opuscula historica (Zwięzly zarys historii) Nikefora Patriarchy, który oprócz Teofanesa opisuje te wydarzenia ${ }^{6}$. Ze źródeł wiadomo, że Irena z Aten przybyła do Konstantynopola ok. 768 roku; Nikefor podaje, że w czasie ósmej indykcji. Jednak Teofanes pisze „pierwszego listopada ósmej indykcji”' Z Z obu źródeł wiemy, że przybyła pod koniec października. Jak to opisuje tekst Teofanesa Wyznawcy:

$\mathrm{Na}$ listopad ósmej indykcji przypada przybycie Ireny z Aten. Przybyła do stolicy z Hierei, eskortowana przez wiele okrętów, typu dromon i chelandia, udekorowanych jedwabiem. Na jej spotkanie wyszli prominenci miasta wraz ze swoimi żonami, którzy poprowadzili ją drogą przed sobą ${ }^{8}$.

\section{Irena jako żona Leona IV (768-780)}

Życie na dworze bizantyńskim musiało być trudne dla młodziutkiej dziewczyny. Zapewne niezwykłe wrażenie wywarła na niej infrastruktura i układ architektoniczny Konstantynopola: Bramy Brązowej, Wielkiego Pałacu (rozbudowanego przez Konstantyna V), kościoła Faros pod wezwaniem Najświętszej Maryi Panny (o którego wnętrzu obecnie nic nie wiadomo poza tym, że został ozdobiony wystawnie i w stylu „rajskiego ogrodu”) .

Po przybyciu na miejsce przeznaczenia Irena musiała się dostosować do zasad i ceremoniału panującego na dworze cesarskim. Jej rola podczas zaręczyn i ślubu ograniczała się do ruchów, gestów i noszenia stroju, które musiały być bardzo starannie przygotowane. Strój stanowił istotny element ceremoniału dworskiego, o czym świadczy specjalne nazewnictwo poszczególnych jego elementów ${ }^{10}$. Cesarzowa została dokładnie wdrożona w ceremoniał zaślubin, które odbyły się 17 grudnia 769 roku i trwały parę dni. Uroczystość ta potwierdziła pozycję Leona IV, który przyjął tytuł basileusa. Aktu koronacji dokonał Konstantyn $\mathrm{V}^{11}$.

\footnotetext{
${ }^{5}$ J. Herrin, Bizancjum: niezwykłe dziedzictwo średniowiecznego imperium, przeł. N. Radomski, Poznań 2013, s. 211.

${ }^{6}$ Cyt za: J. Herrin, Krwawe..., s. 70.

7 Teofanes, Chr., s. 613.

8 Teofanes, Chr., s. 613 (AM 6261). Cytaty z dzieła Teofanesa w przekładzie własnym, na podstawie angielskiego tłumaczenia C. Mango i R. Scotta; AM = Anno Mundi, rok od stworzenia świata w rachubie stosowanej przez Teofanesa.

9 M.-M. SPIESER, Sztuka, [w:] Świat Bizancjum. Cesarstwo Bizantyńskie 641-1204, przekł. A. GrABoŃ, red. J.-C. Cheynet, Kraków 2011, s. 420.

${ }^{10}$ F. Boucher, Historia mody. Dzieje ubiorów od czasów prehistorycznych do końca XX wieku, Warszawa 2006, s. 118-121.

${ }^{11}$ J. Herrin, Krwawe..., s. 74.
} 
Rozpatrując elementy ceremoniału koronacji, można przedstawić jego układ w ten sposób:

- ubranie cesarzowej Ireny w strój,

- prezentacja arystokracji przed cesarzową, całowanie przez urzędników kolan cesarzowej i cesarza,

- aklamacja bezpośrednia (osobista) cesarzowej i cesarza przez każdego urzędnika w portyku przy Augustejonie,

- przejście orszaku do części Augustejonu ${ }^{12}$ nazwanej Onopodion (czyli Ośla Noga), gdzie cześć Irenie oddali patrycjusze,

- oddanie przez Irenę czci krzyżowi,

- okrzyknięcie Ireny cesarzową przez lud.

Lista aklamacyjna wyśpiewywana przez lud brzmiała mniej więcej następująco:

Dziś jest wspaniały dzień Pański, dzień zbawienia Rzymian, dzień radosny i chwalebny dla świata, w którym korona cesarstwa słusznie została włożona na Twe skronie. Chwała Bogu, który jest Panem wszechrzeczy! Chwała Bogu, który uczynił Cię cesarzową! Chwała Bogu, który ukoronował Twą głowę. Niech ten, co Cię własną ręką ukoronował, Ireno, zechce zachować Cię w purpurze przez długie lata na chwałę i ku radości Rzymian ${ }^{13}$.

W trzecim dniu po zaślubinach cesarzową czekała rytualna kąpiel. Symbolicznie oznaczała zapewne „narodzenie się” nowej cesarzowej. Najpierw odbywały się aklamacje urzędników, polityków z fakcji Błękitnych i Zielonych. Następnie w towarzystwie dostojników dworskich korytarzami Wielkiego Pałacu Irena udała się do łaźni ${ }^{14}$.

Dwa wydarzenia sprawiły, że cesarzowa Irena mogła się czuć pewna swojej pozycji na dworze. Śmierć Konstantyna V pozwoliła jej zdobyć silną pozycję w cesarstwie. Dodatkowo aranżowała małżeństwo swojej krewnej z władcą bułgarskim Telerygiem, licząc na umocnienie więzi między Bułgarami a Bizantyńczykami.

Małżonków Irenę i Leona IV mógł dzielić sposób patrzenia na kult ikon. Jej mąż, w przeciwieństwie do swego ojca Konstantyna V, był umiarkowanym ikonoklastą. Natomiast Irena, zdaniem kronikarzy, m.in. Kedrenosa, potajemnie oddawała cześć ikonom ${ }^{15}$. Kłopotem jest brak wiarygodnych informacji na temat stosunku małżonków do kultu ikon. Teofanes o sporze między nimi na tym tle w ogóle nie wspomina. Natomiast Kedrenos, który snuje opowieść o sporze małżonków i zaprzestaniu przez Leona IV dzielenia z małżonką łoża ${ }^{16}$, albo wymyślił taką historię, albo przedstawia swoją wersję wydarzeń.

\footnotetext{
12 S. Bralewski, M.J. LeszKa, K. Marinow, T. Wolińska, Kształt urbanistyczny miasta, [w:] Konstantynopol. Nowy Rzym. Miasto i ludzie w okresie wczesnobizantyńskim, red. M.J. LeszKA, T. WolińSKA, Warszawa 2011, s. 103. Augustejon - jeden z dwóch placów rzymskiego Byzantion. Wcześniej był nazywany Tetrastoon. Nazwa miasta wywodzi się od srebrnego posągu matki Konstantyna Wielkiego, augusty Heleny, który postawiony został w centrum placu.

${ }^{13}$ Ceremonia opiera się na rytuale koronacji przewidzianym dla cesarza. J. Herrin, Krwawe..., s. 76.

${ }^{14}$ Ibidem, s. 78.

15 Ibidem, s. 86.

16 Ibidem.
} 
Para cesarska doczekała się potomka. Ok. 771 roku przyszedł na świat Konstantyn VI. Oprócz Konstantyna VI cesarzowa Irena nie miała więcej dzieci, ponieważ nie mogła zajść później w ciążę.

Rola cesarzowej Ireny automatycznie zmieniła się wraz z narodzinami syna w Porfirowej Komnacie pałacu ${ }^{17}$. Same narodziny w tym miejscu powodowały nadanie dziecku tytułu Porfirogenety ${ }^{18}$.

Z narodzinami cesarskiego syna także wiąże się pewien ceremoniał:

- gratulacje składane cesarzowi przez senat, procesja do Wielkiego Kościoła i nabożeństwo odprawiane przez patriarchę,

- igrzyska na hipodromie, na chwałę syna cesarza, który wkrótce przejmie władzę w Cesarstwie,

- napitek lochozema ('bulion z kołyski'), w mieście ten napój rozlewano przez siedem dni na głównej ulicy,

- gratulacje składane cesarzowej przez cały dwór.

- Przez czterdzieści dni uznawano cesarzową za nieczystą. Dlatego potrzebny był jej rytuał oczyszczenia ${ }^{19}$.

Nagła śmierć męża 8 września 780 roku postawiła Irenę w całkowicie nowej sytuacji.

\section{Irena jako regentka - okres małoletniości Konstantyna VI (780-797)}

Po śmierci cesarza Leona IV, w związku z małoletniością Konstantyna VI, ustanowiono radę regencyjną, do której weszli obok cesarzowej Ireny patriarcha Paweł oraz inni urzędnicy cywilni i wojskowi. Wybijane około 780 roku monety jak najbardziej podkreślały wspólną władzę matki i syna. Przedstawiają one Konstantyna VI po prawej stronie krzyża, a jego matkę Irenę po lewej. Z kolei na rewersie widać Leona III, Konstantyna V, Leona IV ${ }^{20}$.

Było wielu chętnych do odebrania tronu matce i synowi. Pretendentami, którzy próbowali przejąć władzę, byli młodsi synowie Konstantyna V. Gdy syn Ireny miał dziesięć lat, czyli w początkowych latach regencji, spisek przygotował najstarszy z nich Nikefor. Intryga została wykryta i wielu wybitnych urzędników: Bardas (naczelnik Armeniakonu), Grzegorz (logoteta do spraw zagranicznych i wewnętrznych), Konstantyn (domestyk, przywódca ekskubitów) oraz Teofilakt Rangabeusz (dowódca floty Dodekanezu), utraciło dotychczas sprawowane przez

\footnotetext{
${ }^{17}$ Dyskusje nad datą urodzenia syna cesarzowej Ireny, por.: Teofanes, Chr. s. 614 i i 647-649 (AM 6262 i AM 6289); J. Herrin, Krwawe..., s. 79; J. Herrin, The Imperial Feminine in Byzantium, „Past and Present” 169 (2000), s. 3-35.

${ }_{18}$ J. Herrin, Krwawe..., s. 79.

${ }^{19}$ Opisy tych ceremonii zaczerpnęłam z: J. Herrin, Krwawe..., s. 79.

${ }^{20}$ Ibidem, s. 177.
} 
siebie urzędy. Irena kazała ich wszystkich przykładnie ukarać i wygnać. Z kolei Nikeforowi i jego braciom nakazała przyjąć niższe święcenie duchowne, co oznaczało nie tylko brak możliwości ożenku, ale także pozostawanie na najniższym szczeblu kleru w Bizancjum: stawali się subdiakonami lub anagnostesami ${ }^{21}$.

Okresu regencji cesarzowej Ireny (780-790) nie można uznać za czas prowadzenia przez nią samodzielnej polityki, ponieważ musiała liczyć się wtedy ze zdaniem patriarchy Pawła i wychowywać syna na przyszłego władcę. Rozpoczęła jednak bardzo aktywną politykę zagraniczną. Irena w imieniu własnym i syna wysłała poselstwo na dwór władcy Franków Karola Wielkiego. Końcowe rozmowy zakończyły się pomyślnie i jedna z córek Karola, Rotruda, zaręczyła się z młodym władcą bizantyńskim ${ }^{22}$. Nazywano ją po grecku Erythro, czyli Czerwona. W celu kształcenia młodej dziewczyny wysłano z Konstantynopola eunucha Elizeusza, żeby uczył ją języka greckiego. Oto jak opisuje dyplomatyczne pertraktacje Teofanes:

\begin{abstract}
W tym roku Irena wysłała sakelariosa Konstansa i primikeriosa Mamalosa do Karola, króla Franków, żeby doprowadzić do zaręczyn jego córki Erythro ze swoim synem, cesarzem Konstantynem. Po zawarciu porozumienia i wymianie przysiąg pozostawiono notariusza eunucha Elizeusza, aby nauczył Erythro mówić i pisać w języku greckim i zwyczajów panujących w imperium rzymskim² ${ }^{23}$.
\end{abstract}

Z tekstu kroniki Teofanesa można się dowiedzieć, jak Irena rządziła i jaką silną władzę posiadała. Tych, którzy się jej nie podobali, po prostu skazywała na wygnanie i wycięcie tonsury. Logoteta Grzegorz, strateg Armenii Bardas, Konstantyn, syn Wikariusza i Teofilakt, syn Rangabeusza, który był drungariosem ${ }^{24}$ Dodekanezu, zostali skazani na wygnanie. Jednocześnie cesarzowa Irena mianowała nowych urzędników, m.in. patrycjusza Elpidiusza, stratega Sycylii. Jednak i on później miał stracić swój urząd, dodatkowo został ubiczowany i wycięto mu tonsurę.

Teofanes upatruje we władzy Konstantyna i cesarzowej Ireny interwencję Boga. Dodatkowo pisarz wspomina o trumnie znalezionej w trakcie kopania wałów trackich, z inskrypcją:

Chrystus narodzi się z Dziewicy Maryi i wierzę w Niego. O, słońce, będzie ciebie można zobaczyć za panowania Konstantyna i Ireny ${ }^{25}$.

Tłumacz dzieła Teofanesa nie wyklucza, iż tę inskrypcję podano z powodów politycznych, miała ona utrwalić pamięć o osobach władców.

\footnotetext{
${ }^{21}$ Teofanes, Chr., s. 627 (AM 6272).

22 J. Herrin, Krwawe..., s. 92.

23 Teofanes, Chr., s. 628 (AM 6274).

${ }^{24} \mathrm{Tj}$. dowódcą wojskowym, którego obowiązkiem było zapewnienie bezpieczeństwa cesarzowi w pałacu i podczas wyprawy wojennej (Encyklopedia kultury bizantyńskiej, red. O. JuREWICz, Warszawa 2002, s.149).

25 Teofanes, Chr., s. 627 (AM 6273)
} 
Około 783 r. cesarzowa zaczyna się angażować w spór o ikony. Teofanes Wyznawca uważa, że stało się tak, ponieważ pewnego razu zastała patriarchę Pawła smutnego. W rozmowie żalił się jej na los księży i zakonników. Wówczas zaczęła ingerować w politykę związaną z kultem ikon. Na zebraniu osób duchownych ich rozmowa w tej sprawie wyglądała tak:

Oni powiedzieli do niego: „Dlaczego więc w momencie swoich święceń podpisałeś się pod zarządzeniem, że nie wolno czcić ikon?”. On odpowiedział: „Z tego właśnie powodu płaczę i schroniłem się w pokucie, modląc się do Boga, aby nie ukarał mnie jako kapłana, który do tej pory pozostawał cichy i nie objawiał prawdy w obawie przed waszą złością?26.

Spowodowało to, iz:

Od tego właśnie momentu zagadnienie świętych ikon zaczęło być otwarcie dyskutowane i omawiane przez wszystkich ${ }^{27}$.

Rok później Irena wystosowała prośbę do senatu o powrót do ortodoksji i zaprzestanie prześladowania ikonofilów. $Z$ tego właśnie powodu zrezygnował ze swego urzędu patriarcha Paweł i rozpoczął życie zakonne. Nowo mianowanym biskupem został 25 grudnia 784 r. Tarazjusz. W roku 786 Irena zwołała sobór do Konstantynopola, mający poprzeć czcicieli ikon. Zamiar ten jednak został udaremniony przez wrogie kultowi ikon oddziały wojska stacjonujące w Konstantynopolu. Na zwołanym w 787 roku soborze w Nicei oficjalnie przywrócono kult ikon. Był to siódmy sobór ekumeniczny. Zgromadził 350 biskupów.

W 788 roku syn Ireny z polecenia matki ożenił się z armeńską księżniczką Marią z Amnii, co opisuje dziejopis:

Cesarzowa Irena zerwała umowę z Frankami i wysłała protospathariosa Teofanesa, który przyprowadził pannę z Armeniakon, Marię z Amnii. Wydała ją za mąż za swojego syna, cesarza Konstantyna, który był temu niechętny i bardzo strapiony z powodu swojego związku z córką Karola, króla Franków, z którą był wcześniej zaręczony. Jego ślub był celebrowany w miesiącu listopadzie, 12 . indykcji ${ }^{28}$.

Irena w tym roku wysłała także poselstwo do Longobardów, aby przeciągnąć na swoją stronę przeciwników króla Franków.

Teofanes Wyznawca opisuje wzajemne relacje matki i syna na przełomie lat 789/790, w dziesiątym roku ich rządów:

W tym samym roku źli ludzie za namową Szatana, niechętnego wobec cesarskiej pobożności, nastawili matkę przeciwko własnemu synowi a syna przeciwko własnej matce. Przekonali ją, że zostali poinformowani przez przepowiednie o tym, iż: „Jest zarządzone przez Boga, że Twój syn nie powinien otrzymać Cesarstwa, bo jest ono

\footnotetext{
26 Teofanes, Chr., s. 631 (AM 6276).

27 Teofanes, Chr., s. 631 (AM 6276).

${ }^{28}$ Teofanes, Chr., s. 637 (AM 6281).
} 
Twoje, przyznane Ci przez samego Boga”. Oszukana, jak kobieta, którą była, i będąc zarazem ambitną, była usatysfakcjonowana, iż rzeczy układały się istotnie w taki sposób, i nie dostrzegła, że ci mężczyźni przedstawili powyższy pretekst, ponieważ ich celem było zarządzanie sprawami państwa ${ }^{29}$.

Ten fragment pokazuje, ile osób z najbliższego grona było przeciwko niej. Irena, mimo wszystko, zgromadziła wokół siebie krąg swoich eunuchów (m.in. Stauracjusza), aby móc później przejąć władzę. Konstantyn słuchał złych rad matki i jej współpracowników, mimo że wszystkie wcześniejsze wydarzenia wskazywały na to, iż otoczenie $\mathrm{z}$ dworu matki nie było mu przychylne.

W tym samym roku Irena zyskuje coraz większą władzę, jak na razie dyskwalifikując najbliższych współpracowników syna (m.in. magistra Piotra). W 790 roku zawiązał się jednak spisek, w wyniku którego Irena została odsunięta od władzy, a jej syn ustanowiony jedynowładcą. Po przejęciu władzy przez Konstantyna VI już na początku widoczna staje się rywalizacja między matką a synem, ponieważ aresztowano eunucha Stauracjusza, który zarządzał administracją cesarstwa. Został aresztowany przez ludzi bliskich cesarzowi. Irena, mszcząc się na synu, kazała zaaresztować wszystkich ludzi z jego otoczenia. Na podstawie tych wydarzeń można wywnioskować, że stosunki między matką a synem nie układały się najlepiej. W walce o władzę Konstantyn stawał się dla urzędników Ireny okrutny. Wychłostał jej eunuchów, logotetę Staraucjusza i ministra Aecjusza, wygolił im tonsury i wygnał w różne miejsca. Matkę zamknął w pałacu Eleuterios, myśląc, że tam pozostanie, co opisuje Teofanes Wyznawca:

Gdy cesarz powrócił do miasta w grudniu, kazał wychłostać Stauracjusza, wygolił mu głowę i skazał na wygnanie do temu Armeniakon, tak aby ci ostatni [jego współpracownicy] byli usatysfakcjonowani. Skazał także na wygnanie eunucha Aecjusza - protospathariosa będącego zarazem powiernikiem Ireny, i wszystkich pozostałych eunuchów z jej dworu ${ }^{30}$.

Samodzielne rządy Konstantyna przetrwały do stycznia 792 roku. Irena i jej współpracownicy stale naciskali na Konstantyna, aby przywrócił miejsce należne matce jako cesarzowej, a najbliżsi współpracownicy Konstantyna, niezadowoleni z jego rządów, zaczęli popierać jego matkę. Ulegając tym wpływom, cesarz przywrócił Irenie prawo do pałacu i tronu.

Panowanie wspólne matki i syna nie było źle wspominane w Bizancjum, co udowodnił Teofanes w swojej kronice:

15 stycznia po błaganiach ze strony swej matki i wielu osób posiadających autorytet, cesarz raz jeszcze ogłosił ją cesarzową i była ona aklamowana wraz z nim tak jak na początku: „Niech żyją długo Cesarz Konstantyn i Cesarzowa Irena” ${ }^{31}$.

\footnotetext{
29 Teofanes, Chr., s. 638(AM 6282).

30 Teofanes, Chr., s. 641 (AM 6283).

31 Teofanes, Chr., s. 642 (AM 6284).
} 
W ciągu całego swojego panowania Konstantyn VI popełniał liczne błędy, które kosztowały go utratę dobrej opinii, jak w przypadku oddalenia żony Marii, która urodziła mu dwie córki. W 795 roku zmusił Marię do zostania mniszką i w sierpniu tego roku ukoronował nową cesarzową, która miała na imię Teodote i była dwórką cesarzowej Ireny. Drugiego małżeństwa Konstantyna VI nie chciał pobłogosławić patriarcha Tarazjusz (bliski współpracownik cesarzowej). Pobłogosławił je natomiast kapłan Józef (bez żadnych konsekwencji ze strony patriarchy) ${ }^{32}$.

W 796 roku Konstantyn VI towarzyszył matce i całemu dworowi w wyprawie do Prusy $^{33}$. Gdy dowiedział się, że Teodote rodzi mu syna, którego później nazwano Leonem, pośpieszył do stolicy. Leon zmarł 1 maja 797 roku, mając zaledwie 7 miesięcy $^{34}$.

Irena wykorzystała trudne dla Konstantyna VI chwile. Zacieśniała wokół niego sieć i oddalała od cesarza sojuszników. Widząc, że szykuje się ostateczna rozgrywka z matką, w sierpniu 797 roku cesarz próbował uciec z miasta ${ }^{35}$. Został jednak przechytrzony i sprowadzony do Konstantynopola. Ostatecznie 19 marca 797 roku oślepiono go w Porfirowej Komnacie, po to, aby nigdy więcej nie mógł przejąć władzy. Według Teofanesa słońce schowało się wtedy na siedemnaście dni i nastąpiła całkowita ciemność, która świadczyła o tym, jak Bóg przyjmuje oślepianie synów przez matki. Mimo że w Bizancjum była to powszechna metoda karania uzurpatorów władzy, ta sytuacja była wyjątkowa, gdyż to matka zleciła oślepienie syna. Zazwyczaj robili to mężczyźni. Opis możemy znaleźć u Teofanesa Wyznawcy:

Ukaranie tych mężczyzn miało miejsce w sierpniu, w sobotę piętnastej indykcji, dnia dziewiątego. Jednakże przez długi czas, osąd boży pozostawił ten niesprawiedliwy uczynek niepomszczonym: po przerwie pięcioletniej, w tym samym miesiącu i również w tę samą sobotę Konstantyn został oślepiony przez własną matkę ${ }^{36}$.

\section{Okres samodzielnych rządów cesarskich Ireny (797-802)}

W wyniku przewrotu 15 sierpnia 797 roku Irena stała się samodzielnym władcą, używającym nawet tytułu basileusa. Przejęła niepodzielną władzę w Bizancjum, co przypieczętowano wybiciem złotych monet. $\mathrm{Na}$ awersie i rewersie występuje tylko ona jako jedynowładczyni. Cesarz pozostawał źródłem prawa, w dokumentach używano męskiej odmiany tytułu: basileus (cesarz). Aby umocnić swoją władzę, cesarzowa Irena wydała dwa dokumenty, nowele, które dotyczyły przysiąg i powtórnych małżeństw. Pierwsza z zasad podkreślała zakaz łatwego

\footnotetext{
${ }^{32}$ M. BanaszaK, Historia Kościoła Katolickiego, t. 2: Średniowiecze, Warszawa 1989, s. 35.

${ }^{33}$ Obecnie Bursa w zachodniej części Azji Mniejszej.

${ }^{34}$ Miejsce jego pochówku wymienia Teofanes, Chr., s. 645 (AM 6287).

35 J. Herrin, Krwawe..., s. 112.

36 Teofanes, Chr., s. 643 (AM 6284).
} 
łamania przysiąg małżeńskich, ustanowionych w Kościele. Druga zasada ustanowiona przez nią zakazywała zawierania małżeństw po raz trzeci. Oczywiście podpisała dokumenty jako autokrator.

Lata 799-800 pokazują rywalizację eunuchów na dworze cesarzowej Ireny. Aecjusz i Niketas dążyli do usunięcia Stauracjusza, którego względy bezskutecznie starali się pozyskać. Obaj buntownicy zostali aresztowani i skazani na karę wygnania. Niketasa wysłano do prowincji Kapadocji, gdzie zmarł.

Rządy Ireny umożliwiły powrót do Konstantynopola ludziom niemile widzianym przez wcześniejszych cesarzy. Należeli do nich: Platon - czołowy przywódca duchownych, igumen Sakudion, jego siostrzeńcy Teodor Studyta i Józef. Irena starała się prowadzić dobrą politykę zagraniczną. W 798 roku wysłała misje dyplomatyczne do Arabów i Franków. Obce dwory dostały informacje o przejęciu przez nią władzy i okaleczeniu byłego cesarza oraz propozycje pokoju. Cesarzowa starała się pozyskać dla swojej polityki ludność Konstantynopola. Podobne cele przyświecały jej polityce, kiedy obniżała podatki miejskie i cła nakładane na towary przywożone i wywożone z cesarstwa.

W 797 roku Bizancjum próbuje unormować stosunki z coraz potężniejszym Karolem Wielkim. Cesarzowa Irena myślała o zawarciu małżeństwa z Karolem Wielkim, co można wywnioskować z Kölner Notiz. Jest to krótki tekst łaciński opisujący podróż dyplomatów z Sycylii na dwór frankijski. Celem rozmów było złożenie propozycji małżeństwa Ireny z Karolem. Rok później Irena wysłała do władcy Franków jeszcze dwie legacje ${ }^{37}$. Nie należy traktować tej misji jako próby realizacji planów prawdziwego małżeństwa, ale można ją potraktować jako traktat pokojowy i formę współżycia obok siebie wielkich imperiów. Uwadze władczyni w Konstantynopolu nie mogły ujść kontakty Karola Wielkiego z kalifatem i środowiskami bizantyńskimi w Palestynie ${ }^{38}$. Niekwestionowaną pozycję bizantyńskich władców osłabiła koronacja króla Franków Karola Wielkiego na cesarza. Uroczystość ta odbyła się w 800 roku. Bez względu na to, czy cesarska koronacja Karola była efektem jego świadomych działań, czy inicjatywą papiestwa, uzasadniano ją między innymi tym, że istniał wakat na tronie cesarskim, gdyż Irena jako kobieta - zdaniem Zachodu - cesarzem być nie mogła. Dla Bizancjum koronacja Karola była zwykłą uzurpacją. W roku, w którym Karol został koronowany przez papieża Leona III na cesarza Franków, wiadomo było już, że nie ożeni się z Ireną. W latach 801-802 Irena, wyczuwając, że jej władza słabnie, wysłała emisariuszy na Sycylię i do papieża Leona. Jej działania były pośpieszne, gdyż przeczuwała rosnące siły uzurpatora Nikefora, który już w następnym roku miał doprowadzić do zdjęcia jej z tronu ${ }^{39}$. Niemniej w 802 roku cesarz Karol Wielki przysłał Irenie propozycję sojuszu.

\footnotetext{
${ }^{37}$ J. Shephard, Bizancjum ok. 500-1024, przeł. K. Pachniak, J.S. Partyka, R. Piotrowski, Warszawa 2012, s. 408-409.

38 Teofanes, Chr., s. 408.

39 Teofanes, Chr., s. 654 (AM 6295).
} 
Mimo tych perturbacji, za czasów panowania Ireny kontakty z Frankami przebiegały stosunkowo spokojnie, bez większych kłopotów dyplomatycznych ${ }^{40}$.

\section{Koniec rządów Ireny i ostatnie miesiące jej życia (802-803)}

Cesarzowa zraziła do siebie dworzan tym, że nie ustaliła sukcesji w Cesarstwie Bizantyńskim na wypadek swojej śmierci. Została pozbawiona władzy w wyniku przewrotu przeprowadzonego przez Nikefora 31 października 802 roku. Wysłano żołnierzy do bramy pałacu Chalke i otoczono pałac Eleuterios, gdzie mieszkała cesarzowa. W grupie zamachowców znajdowali się: dwaj bracia Tryfylliosowie, sakellarios Leon z Synopy, kwestor Teoktyst, Grzegorz (były dowódca temu Opsikon), Piotr (dowódca scholaj) oraz Leon Sarantapechopos (prawdopodobnie krewny Ireny). Władzę przejął Nikefor, ale nie na długo (rządził do 811 roku). W listopadzie 802 roku, gdy zima była surowa, cesarzową Irenę wysłano na wyspę Lesbos i nikt nie mógł jej odwiedzać. Gdy ujawniła miejsce ukrycia swoich kosztowności, została wygnana do klasztoru na Prinkipo, gdzie zmarła. Tam też chciała być pochowana.

Działania cesarzowej Ireny różniły się pod pewnymi względami od rządów innych cesarzy dynastii syryjskiej. Głównym jej dążeniem, ale nie jedynym, było popieranie przez cesarzową ikonofilstwa. Ustanowiła ona również pośrednią władzę między cesarzem i administracją. Jej pośrednikami byli eunuchowie z Cesarskiej Sypialni. Posunięciem nowatorskim jak na tamte czasy było wybranie patriarchy spośród laikatu ${ }^{41}$.

Ogromnym błędem, jaki można zarzucić cesarzowej Irenie, jest to, że nie powołała nikogo na swego następcę. Spowodowało to zmianę rodu panującego. Swoją politykę religijną cesarzowa Irena prowadziła w taki sposób, że została zapamiętana i opisana przez potomnych.

\footnotetext{
40 Teofanes, Chr., s. 409.

${ }^{41}$ J. Shepard, op. cit., s. 281. Irena prowadziła również działania wojenne, ale nie umiała zarządzać ruchami wojsk. Rozwiązała i rozproszyła elitarne korpusy wojskowe, który rozbiły synod w 786 roku.
} 